\author{
Pathophysiology \\ of Haemostasis \\ and Thrombosis
}

\title{
Assessment of Endothelial Dysfunction: Focus on Atherothrombotic Disease
}

\author{
Andrew D. Blann \\ Haemostasis, Thrombosis, and Vascular Biology Unit, University Department of Medicine \\ City Hospital, Birmingham, United Kingdom
}

\section{Key Words}

Endothelial cell · von Willebrand factor · Flow

mediated dilatation . Soluble E-selectin · Circulating endothelial cells

\begin{abstract}
As the endothelium is crucial to cardiovascular disease, the accurate assessment of this organ is a valuable tool, especially if such assessments are clinically relevant. As functions of the endothelium focus on haemostasis and the maintenance of correct vascular tone, and dysfunction results in changes that promote thrombosis and hypertension, thus assessment of endothelial function therefore follows these processes. Foremost in the plasma markers of vascular function is von Willebrand factor, a molecule that interacts with platelets. Lack of nitric oxide results in poor blood pressure control that can be quantified by impaired flow mediated dilatation. More recently, increased numbers of circulating endothelial cells have been described that indicate severe damage to the endothelium. Unsurprisingly, these three markers correlate with each other and former two predict adverse outcome in long-term follow up studies. The assessment of vascular damage is becoming recognised as having an increasingly prominent part in the pathophysiology of cardiovascular disease.
\end{abstract}

\section{KARGER}

Fax +4161306 1234

E-Mail: karger@karger.ch

www.karger.com
Copyright @ 2004 S. Karger AG, Basel

(C) 2004 S. Karger AG, Basel

$1424-8832 / 04 / 0336-0256 \$ 21.0 / 0$

Accessible online at: www.krager.com/pht

\section{Introduction}

If collected together, the endothelium is an organ weighing perhaps 1 kilogram, consisting of 1 to $6 \times 10^{13}$ cells and covering an area of 1 to $7 \mathrm{~m}^{2}$ [1]. Elsewhere, this has been equated to a mass of five normal hearts and in area to half a dozen tennis courts per standard $70 \mathrm{~kg}$ man [2]. Good performance of this organ is essential if the development and progression of atherothrombotic disease is to be resisted. Indeed, (pathological) damage to the endothelial cell (EC) and the resulting (physiological) dysfunction links health, the major risk factors such as diabetes, and the presence of clear disease as suggested by stroke and myocardial infarction (Figure 1).

Our approach to endothelial dysfunction considers firstly normal EC functioning such as in providing an anti-coagulant and anti-platelet surface, regulating fluid movement from the blood to the tissues, and correctly regulating blood vessel tone. The former is mediated by the release of molecules such as nitric oxide and prostacyclin and the presence of anti-coagulant molecules such as ectonucleotidase (CD39) and thrombomodulin (CD141) at the cell surface. However, ECs also produces pro-coagulants such as von Willebrand factor (vWf), coagulation factor $\mathrm{V}$, and tissue factor. Correct vascular tone is regulated by a balance of vasodilators (such as nitric oxide and prostacyclin), and vasoconstrictors (such as endothelin). A healthy response to

Andrew D Blann PhD FRCPath

Haemostasis, Thrombosis, and Vascular Biology Unit

University Department of Medicine, City Hospital

Birmingham B18 7QH, UK

Tel/Fax: + 44121507 5076; E-mail: a.blann@bham.ac.uk 


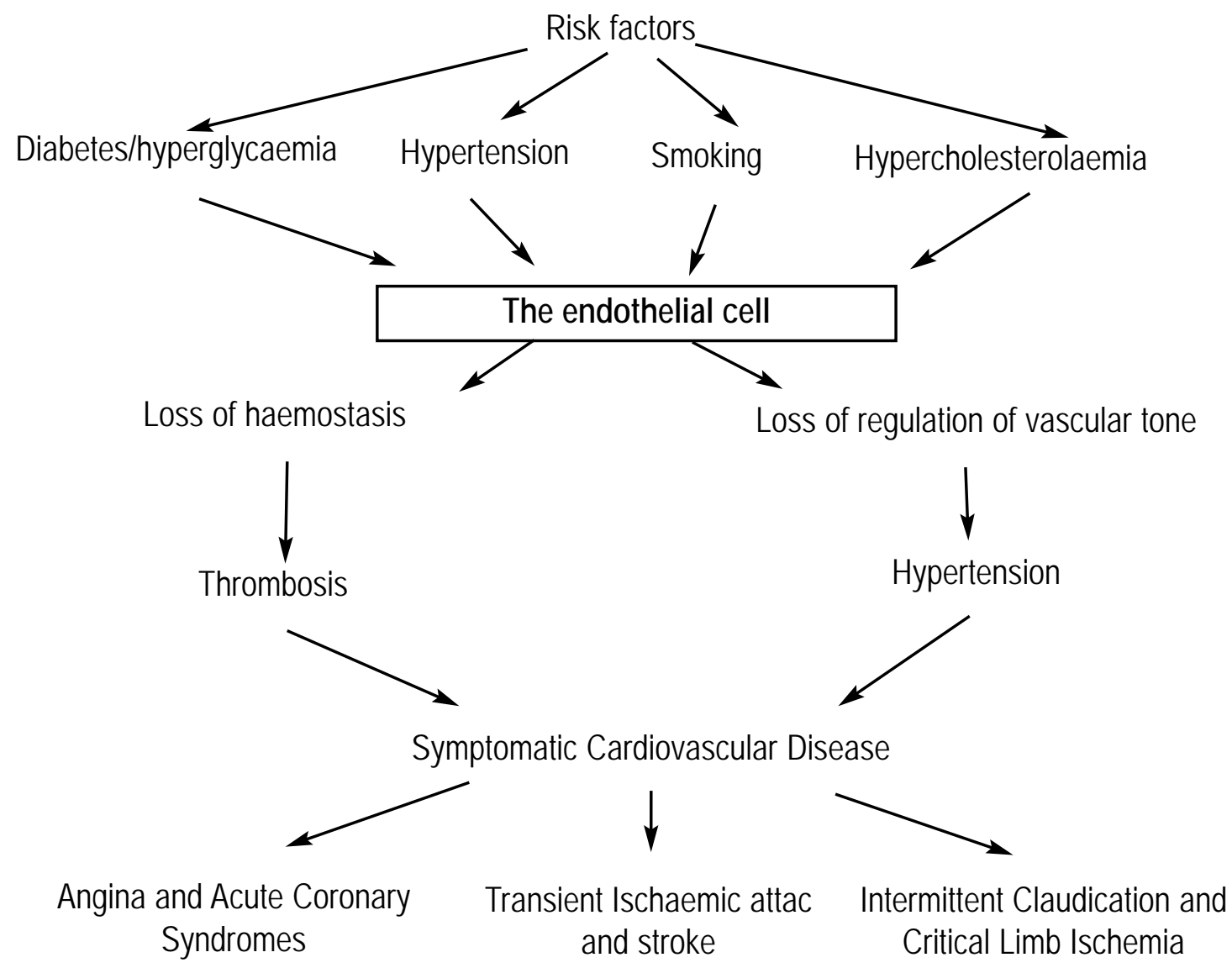

Fig. 1. Position of the endothelium in the pathogenesis of atherothrombotic disease.

a localised inflammation is the transient increase in the expression of cell adhesion molecules such as E-selectin (CD62E) that aid the process of trans-endothelial migration by leukocytes. Thus a dysfunctional endothelium that fails in these tasks instead (respectively) promotes thrombosis, oedema, hypertension and increased leukocyte adhesion.

Assessment of endothelial dysfunction therefore follows these leads and focus on three techniques: (i) the release of molecules into the plasma, (ii) the impaired vasodilator responses to an appropriate stimulus, and (iii) increased numbers of ECs in the plasma (i.e. circulating endothelial cells, CECs). Loss of endothelial functioning in regulating fluid movement (resulting in oedema) is difficult to quantify.

\section{Plasma Markers of Endothelial Function}

The endothelium produces/releases a large number of molecules, although few are both specific for this organ and easy to measure in the clinic or the laboratory (Table 1). Of those that remain, vWf, soluble thrombomodulin (sTM) and soluble E selectin have been extensively studied by ELISA. The latter two molecules are normally cell surface constituents that can be cleaved or digested away to yield forms measurable in the plasma. Although tissue plasminogen activator is EC-specific, a variable proportion circulates bound to plasminogen activator inhibitor, leading to difficulties in interpretation if defined simply by structural ELISA [3]. Numerous groups have reported that raised vWf is a risk factor for coronary artery disease (CAD) and stroke on a variety of backgrounds although this relationship may not be causal [4-7]. Early work suggested that raised sTM may be useful in predicting atherothrombotic events [3], and although this has been questioned most recent data suggests it predicts stroke, not myocardial infarction [8,9]. The Atherosclerosis Risk in Communities Study (ARIC), recruiting 792 subjects, demonstrated a significant association between levels of soluble E-selectin and occurrence of carotid artery atherosclerosis [10]. Curiously, in a study of hyperlipidemic patients who went on to experience a cardiovascular event, high levels of vWf, but low levels of soluble E-selectin, predicted a poor outcome [11]. In a differ- 
ent follow-up of hypertensive patients, both vWf and soluble E-selectin levels decreased with the control of blood pressure, but only vWf was a predictor of the appearance or progression of atherosclerosis [12]. These two studies (and others) demonstrate a difference in vWf and soluble Eselectin responses, suggesting the two molecules reflect different aspects of vascular physiology. For example, perhaps raised soluble E-selectin is related more to increased endothelial cell regeneration after cell damage caused by the progression of the disease. Galen has recently concluded that although soluble E-selectin may reflect vascular dysfunction during hypertension, it is not a factor of prognostic value concerning the development of target organ damage [13]. Notwithstanding high baseline levels of soluble Eselectin found in type 2 diabetic patients, this molecule failed to predict death after a mean of 9 years [14], although several other molecules were predictors. Despite high levels of both soluble E-selectin and STM in myocardial infarction patients, only the latter (said to reflect endothelial injury) was able to predict a poor outcome after 49 months of follow-up [15].

Table 1. Products of the endothelium

\begin{tabular}{ll}
\hline Anticoagulant/antithrombotic & thrombomodulin \\
& heparin \\
& protein C \\
& protein S \\
& tissue plasminogen activator \\
& prostacyclin \\
& nitric oxide \\
Procoagulant/prothrombotic & von Willebrand factor (vWf) \\
& factor V \\
& plasminogen activator inhibitor \\
& thromboxane \\
& tissue factor \\
& E selectin \\
& Inter-cellular adhesion molecule \\
& Vascular cell adhesion molecule \\
& Interleukins 1, 6 and 18 \\
& Tumour necrosis factor \\
& Monocyte chemotactic factor-1 \\
\hline
\end{tabular}

In patients admitted acutely with suspicion of CAD, soluble E-selectin was not a significant predictor of early outcome at three months $[16,17]$. Similar results were obtained after 6 months of follow-up, from patients suffering from stable [18] and unstable angina (and non-Q wave myocardial infarction) [19]. In a small cross-sectional study, soluble E selectin failed to discriminate between 60 patients with angiographically proven coronary artery disease and 60 individuals without evidence of stenosis [20]. In a large cohort of 1246 patients with angiographically-proven CAD, soluble E-selectin levels (and also C-reactive protein and fibrinogen) were significantly related to future cardiovascular death, although this disappeared on adjustment for clas- sical risk factors, age, sex and other markers [22]. In the smaller British Regional Heart Study of 643 men, Malik et al, reported an odds ratio of 1.13 (95\% CI 0.78-1.62) for adjusted soluble E-selectin, concluding that measurement of this molecule is unlikely to add much predictive information to that provided by more established risk factors [22]. A definitive, large and therefore well powered, head-to-head study of these three molecules will define which has most to offer.

\section{Flow Mediated Dilatation}

Evidence of the importance of the endothelium in regulating blood pressure was stimulated in 1980 by Furchgott and Zadowski with their discovery of endothelium-derived relaxing factor in an animal in-vitro model, a property subsequently shown to be due to nitric oxide [23]. These observations took on more importance when altered coronary artery vasoreactivity to infused acetylcholine was demonstrated by quantitative angiography in patients with atherosclerosis [24]. However, this dangerously invasive process remained of limited research value until the development by Celermajer and colleagues of the ultrasonic and non-invasive assessment of EC dysfunction, currently evolved into impaired blood flow after a temporary arterial occlusion [25]. In this technique, the response of downstream (i.e. forearm) arteries to the increase in blood flow following the release of a tourniquet over the upper arm is to dilate to facilitate this increased flow of blood, hence flow mediated dilatation (FMD).

Impaired brachial artery FMD is common in atherosclerosis and all its major risk factors, correlates with dysfunction of coronary arteries, and is reversible upon successful treatment of the particular risk factors (e.g. statins for hypercholesterolaemia) for atherosclerosis [26-28]. Notable, this pattern of findings is identical to that of vWf [3-7]. The similarity with this molecule also extends to the ability of impaired FMD to predict the development of major adverse cardiovascular events [28]. Thus, given the close association, albeit in completely different groups of patients and studies, between raised vWf and impaired FMD, it is no surprise that the two have been inversely correlated, i.e. those with the highest vWf have the most impaired FMD, whereas those with low vWf have preserved FMD [29] (Figure 2). Thus a dysfunctional or damaged endothelium not only fails to adequately regulate blood pressure but also releases increased amounts of pro-thrombotic vWf. 


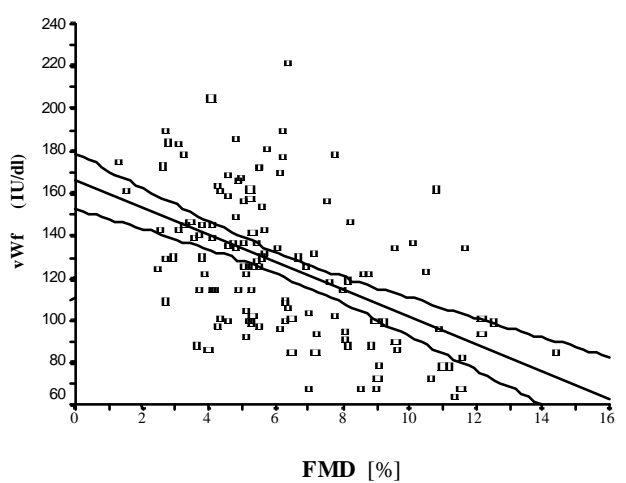

Fig. 2. Correlation between von Willebrand factor and FMD.

\section{Circulating Endothelial Cells (CECs)}

In 1991 George and her colleagues reported a monoclonal antibody to cell surface antigen CD146 on ECs and used it to quantify blood-borne ECs in the blood (i.e. circulating ECs, CECs) in a variety of conditions including rickettsial infection, sickle cell disease, thrombotic thrombocytopenia and acute coronary syndromes (reviewed in [30]).

Table 2. Reports of increased number of CECs

\begin{tabular}{ll}
\hline Condition & Reference \\
\hline Sickle cell anaemia & {$[31]$} \\
Acute coronary syndromes & {$[32]$} \\
Chronic venous insufficiency & {$[33]$} \\
Aortoarteritis & {$[34]$} \\
Cytomegalovirus infection & {$[35,36]$} \\
Septic shock & {$[37]$} \\
Breast cancer and lymphoma & {$[38]$} \\
Systemic lupus erythematosus & {$[39]$} \\
Renal transplant recipients & {$[40,41]$} \\
Inflammatory vasculitis & {$[42]$} \\
Pulmonary hypertension & {$[43]$} \\
Peripheral vascular disease & {$[44]$} \\
Allogeneic bone marrow transplantation & {$[45]$} \\
\hline
\end{tabular}

Solovey et al also used a monoclonal antibody against CD146 to detect CECs in sickle cell anaemia [31]. More recently, various groups have reported increased numbers of CECs in many diverse disease and conditions including cardiovascular disease, cancer, and inflammatory connective tissues disease [32-45] (Table 2). However, these reports are diverse not only in disease studies but also in precise methodology, so that caution in interpretation is necessary.

Perusal of the list of diseases and conditions in table 2 will draw the conclusion that the majority are associated with a severe and injurious pathology. It seems reasonable, therefore, that increased numbers of CECs in the blood are the product of a disease process that irreversibly damages the endothelium. This theory is intrinsically attractive, given the knowledge of the pathophysiology of conditions in which CECs were found, such as established vascular damage in cardiovascular disease and the 'response to injury' theory of atherosclerosis [46].

As previously discussed, numerous epidemiological studies have shown that increased levels of plasma markers such as vWf, tissue plasminogen activator, and (to a lesser extent) soluble E selectin are taken to imply some degree of disturbance of the endothelium, be it damage, dysfunction or activation. The inverse relationship between vWf and FMD has been mentioned [29]. Therefore, if increased numbers of CECs do indeed reflect a damaged endothelium, such levels should correlate with plasma markers and with FMD. Therefore, perhaps unsurprisingly, Kas-Deelen et al [35] found that CECs strongly $(\mathrm{p}<0.001)$ correlated with vWf but not soluble E selectin, whilst Makin et al [44] also correlated CECs with vWf $(p=0.002)$. Since vWf is essentially the gold standard plasma marker for endothelial damage [3], this is strong evidence that CECs also reflect severe vascular disturbance. As yet no complete studies of CECs and FMD have been reported but doubtless this data is currently being generated.

\section{Conclusions}

As good endothelial function is desirable and poor endothelial function (i.e. dysfunction) undesirable, therefore assessment of this cell is valuable. Of the three methods, vWf is certainly easiest (ELISA) but the link with pathophysiology is indirect. FMD is only assessable with complex investigations but provides more direct information on the regulation of vascular tone. The presence of increased numbers of CECs is unequivocal demonstration of severe endothelial damage. Thus although all offer different perspectives on vascular physiology, it is unclear which will prove the most useful in helping to unravel the disease process and so provide better patient care.

\section{Note Added in Proof}

Qulici et al [47] have shown that CEC count can be used as an early, specific, independent marker of non-ST-elevation acute coronary syndrome (ACS). Similarly Lee et al [48] found that raised CECs predicted poor cardiovascular outcome at day 30 and 1 years post admission. vWf was not as accurate a predictor as CECs, and these cells largely stained positive for nitritic oxide synthase. These two papers clearly demonstrate the potential of CECs as markers of future adverse events. Chong et al [49] reported raised CECs in congestive heart failure that correlated inversely with flow medated dilatation, positively with vWf, but not at all with another putatuve EC marker, soluble thrombomodulin. 


\section{References}

$>1$ Augustin HG, Kozian DH, Johnson RC. Differentiation of endothelial cells: analysis of the constitutive and activated endothelial cell phenotypes. Bioessays 1994;16:901-906.

$\checkmark 2$ Henderson AH. Endothelium in control. Br Heart J 1991:65;116-125.

3 Blann AD, Taberner DA. A reliable marker of endothelial cell dysfunction: does it exist? $\mathrm{Br}$ Haematol 1995:90;244 248.

$\checkmark 4$ Morange PE, Simon C, Alessi MC, Luc G, Arveiler D, Ferrieres J, Amouyel P, Evans A, Ducimetiere P, Juhan-Vague I; PRIME Study Group. Endothelial cell markers and the risk of coronary heart disease: the Prospective Epidemiological Study of Myocardial Infarction (PRIME) study. Circulation 2004;109:1343-1348.

5 Borawski J, Naumnik B, Mysliwiec M. Circulating endothelial markers and probability of stroke in haemodialysis patients. Blood Coagul Fibrinolysis 2003;14:315-317.

6 Whincup PH, Danesh J, Walker M, Lennon L, Thomson A, Appleby P, Rumley A, Lowe GD. von Willebrand factor and coronary heart disease: prospective study and meta-analysis. Eur Heart J 2002;23:1764-1770.

7 Conway DS, Pearce LA, Chin BS, Hart RG, Lip GY. Prognostic value of plasma von Willebrand factor and soluble P-selectin as indices of endothelial damage and platelet activation in 994 patients with nonvalvular atrial fibrillation. Circulation 2003;107:3141-3145.

8 Salomaa V, Matei C, Aleksic N, Sansores-Garcia L, Folsom AR, Juneja H, Chambless LE, Wu KK. Soluble thrombomodulin as a predictor of incident coronary heart disease and symptomless carotid artery atherosclerosis in the Atherosclerosis Risk in Communities (ARIC) Study: a case-cohort study. Lancet 1999;353:1729-1734.

$\checkmark 9$ Gerdes VE, Kremer Hovinga JA, Ten Cate H, Brandjes DP, Buller HR. Soluble thrombomodulin in patients with established atherosclerosis. J Thromb Haemost 2004;2:200-201.

10 Hwang SJ, Ballantyne CM, Sharret AR, Smith LC, Davis CE, Gotto A, Boerwinkle E. Circulating adhesion molecules VCAM-1, ICAM-1, and Eselectin in carotid atherosclerosis and incident coronary heart disease. Circulation 1997; 96:42194225

11 Blann AD, Miller JP, McCollum CN. Von Willebrand factor and soluble E-selectin in the prediction of cardiovascular disease progression in hyperlipidaemia. Atherosclerosis 1997; 32:151156.

12 Blann AD, Waite MA. Von Willebrand factor and soluble E-selectin in hypertension: influence of treatment and value in predicting the progression of atherosclerosis. Coronary Art Dis 1996;7:143147.

13 Galen FX. Cell adhesion molecules in hypertension: endothelial markers of vascular injury and predictors of target organ damage? J Hypertens 2002; 20:813-816.
14 Stehouwer CDA, Gall MA, Twisk JWR, Knudsen E, Emeis JJ, Parving HH. Increased urinary albumin excretion, endothelial dysfunction, and chronic low-grade inflammation in type 2 diabetes. Progressive, interrelated, and independently associated with risk of death. Diabetes 2002; 51:11571165

15 Blann AD, Amiral J, McCollum CN. Prognostic value of increased soluble thrombomodulin and increased soluble E-selectin in ischaemic heart disease. Eur J Hematol 1997;59:115-120.

16 O'Malley T, Ludlam CA, Riemersa RA, Fox KAA. Early increase in levels of soluble inter-cellular adhesion molecule-1 (sICAM-1). Potential risk factor for the acute coronary syndromes. Eur Heart J 2001;22:1226-1234.

17 Hillis GS, Terrgino C, Taggart P, Killian A, Zhao N, Dalsey WC, Mangione A. Elevated soluble Pselectin levels are associated with an increased risk of early adverse events in patients with presumed myocardial ischaemia. Am Heart J 2002;143:235-241.

$>18$ Wallen NH, Held C, Rehnqvist N, Hjemdahl P. Elevated serum intercellular adhesion molecule-1 and vascular adhesion molecule-1 among patients with stable angina pectoris who suffer cardiovascular death or non-fatal myocardial infarction. Eur Heart J 1999;20:1039-1043.

19 Mulvihill NT, Foley JB, Murphy RT, Curtin R, Crean PA, Walsh. Risk stratification in unstable angina and non-Q wave myocardial infarction using soluble cell adhesion molecules. Heart 2001; 85:623-627.

20 Porsch-Oezcueruemez M, Kunz D, Kloer HU, Luley C. Evaluation of serum levels of solubilized adhesion molecules and cytokine receptors in coronary heart disease. J Am Coll Cardiol 1999; 34:1995-2001.

21 Blankenberg S, Rupprecht HJ, Bickel C, Peetz D, Hafner G, Tiret L, Meyer J. Circulating cell adhesion molecules and death in patients with coronary artery disease. Circulation 2001;104:1336-1342.

22 Malik I, Danesh J, Whincup P. Bhatia V, Papacosta O. Walker M, Lennon L, Thomson A. Soluble adhesion molecules and prediction of coronary heart disease: a prospective study and meta-analysis. Lancet 2001;358:971-975.

23 Furchgott RF, Zawadzki JV. The obligatory role of endothelial cells in the relaxation of arterial smooth muscle by acetylcholine. Nature 1980;288:373-376.

24 Ludmer PL, Selwyn AP, Shook TL, Wayne RR, Mudge GH, Alexander RW, Ganz P. Paradoxical vasoconstriction induced by acetylcholine in atherosclerotic coronary arteries. N Engl J Med 1986;315:1046-1051.

25 Corretti MC, Anderson TJ, Benjamin EJ, Celermajer D, Charbonneau F, Creager MA, Deanfield J, Drexler H, Gerhard-Herman M, Herrington D, Vallance P, Vita J, Vogel R. Guidelines for the ultrasound assessment of endothelial-dependent flow-mediated vasodilation of the brachial artery: a report of the International Brachial Artery Reactivity Task Force. J Am Coll Cardiol. 2002;39:257-265.

26 Vallance P, Vhan N. Endothelial function and nitric oxide: clinical relevance. Heart 2001:856;342-350.
27 Celermajer DS. Endothelial dysfunction: Does it matter? Is it reversible? JACC 1997:30;325-333.

28 Widlansky ME, Gokce N, Keaney JF Jr, Vita JA. The clinical implications of endothelial dysfunction. J Am Coll Cardiol 2003;42:1149-1160

29 Felmeden DC, Blann AD, Spencer CGC, Beevers DG, Lip GYH. A comparison of flow mediated dilatation and von Willebrand factor as markers of endothelial cell function in health and in hypertension: relationship to cardiovascular risk and the effects of treatment. Blood Coag Fibrinolysis 2003:14;425-431.

30 Dignat-George F, Sampol J. Circulating endothelial cells in vascular disorders: new insights into an old concept. Eur J Haematol 2000:65;215-220.

31 Solovey A, Lin Y, Browne P, Choong S, Wayner E, Hebbel RP. Circulating activated endothelial cells in sickle cell anemia. $\mathrm{N}$ Engl $\mathrm{J}$ Med 1997;337:1584-1590.

32 Mutin M, Canavy I, Blann A, Bory M, Sampol J, Dignat-George F. Direct evidence of endothelial injury in acute myocardial infarction and unstable angina by demonstration of circulating endothelial cells. Blood 1999;93: 2951-2958.

33 Janssens D, Michiels C, Guillaume G, Cuisinier B, Louagie Y, Remacle J. Increase in circulating endothelial cells in patients with primary chronic venous insufficiency: protective effect of Ginkor Fort in a randomized double-blind, placebo-controlled clinical trial. J Cardiovasc Pharmacol 1999;33:7-11.

34 Dang A, Wang B, Li W, Zhang P, Liu G, Zheng D, Ruan Y, Liu L. Plasma endothelin-1 levels and circulating endothelial cells in patients with aortoarteritis. Hypertens Res 2000;23:541-544.

35 Kas-Deelen AM, Harmsen MC, De Maar EF, Oost-Kort WW, Tervaert JW, Van Der Meer J, Van Son WJ, The TH. Acute rejection before cytomegalovirus infection enhances von Willebrand factor and soluble VCAM-1 in blood. Kidney Int 2000;58:2533-2542.

36 Kas-Deelen AM, de Maar EF, Harmsen MC, Driessen C, van Son WJ, The TH. Uninfected and cytomegalic endothelial cells in blood during cytomegalovirus infection: effect of acute rejection. J Infect Dis 2000;181:721-724.

37 Mutunga M, Fulton B, Bullock R, Batchelor A, Gascoigne A, Gillespie JI, Baudouin SV. Circulating endothelial cells in patients with septic shock. Am J Respir Crit Care Med 2001;163:195200.

38 Mancuso P, Burlini A, Pruneri G, Goldhirsch A, Martinelli G Bertolini F. Resting and activated endothelial cells are increased in the peripheral blood of cancer patients. Blood 2001;97:36583661.

39 Clancy R, Marder G, Martin V, Belmont HM, Abramson SB, Buyon J. Circulating activated endothelial cells in systemic lupus erythematosus: further evidence for diffuse vasculopathy. Arthritis Rheum 2001;44: 1203-1208.

40 Popa ER, Kas-Deelen AM, Hepkema BG, van Son WJ, The TW, Harmsen MC. Donor-derived circulating endothelial cells after kidney transplantation. Transplantation 2002;74;1320-1327. 
41 Woywodt A, Schroeder M, Gwinner W, Mengel M, Jaeger M, Schwarz A, Haller H, Haubitz M. Elevated numbers of circulating endothelial cells in renal transplant recipients. Transplantation 2003;76:1-4.

42 Woywodt A, Streiber F, de Groot K, Regelsberger $\mathrm{H}$, Haller H, Haubitz M. Circulating endothelial cells as markers for ANCA-associated small-vessel vasculitis. Lancet 2003;361:206-210.

43 Bull TM, Golpon H, Hebbel RP, Solovey A, Cool CD, Tuder RM, Geraci MW, Voelkel NF. Circulating endothelial cells in pulmonary hypertension. Thromb Haemost 2003;90:698-703.
44 Makin A, Chung NAY, Silverman SH, Blann A, Lip GY. Assessment of endothelial damage in atherosclerotic vascular disease by quantification of circulating endothelial cells. Eur Heart J 2004;25:371-376

45 Woywodt A, Scheer J, Hambach L, Buchholz S, Ganser A, Haller H, Hertenstein B, Haubitz M. Circulating endothelial cells as a marker of endothelial damage in allogeneic hematopoietic stem cell transplantation. Blood 2004;103:36033605.

46 Ross R. The pathogenesis of atherosclerosis: a perspective for the 1990s. Nature 1993;362:801809.
47 Quilici J, Banzet N, Paule P, Meynard JB, Mutin $\mathrm{M}$, Bonnet JL, et al. Circulating endothelial cells count as a diagnostic marker for non-ST elevation acute coronary syndromes. Circulation 2004; 110: 1586-1591

48 Lee KW, Lip GY, Tayebjee M, Foster W, Blann AD. Circulating endothelial cells, Von Willenbrand Factor, interleukin 6 and prognosis in patients with acute coronary syndromes. Blod 2004 sep 16 [Epub ahead of print]

49 Chong AY, Blan D, Patel J, Freestone B, Hughes E, Lip GY. Endothelial dysfunction and damage in gongestive heart failure. Relation of flow mediated dilation to circulaing endothelial cells, plasma indexes of endothelial damage and brain natriuretic pepide. Circulation 2004; 101: 1794-1798. 